\title{
Investigation of Ageing Behaviour of Nitrile- -Butadiene Rubber with Added Graphene in an Accelerated Thermal Ageing Environment
}

\author{
F.-Z. Li, ${ }^{*}$ M.-R. Gao, and B. Guo \\ Baoji University of Arts and Sciences, School of Mechanical, Baoji 721 007, P.R. China
}

\begin{abstract}
In this paper, the thermal ageing of nitrile-butadiene rubber (NBR) reinforced with different graphene (GE) concentrations has been investigated. NBR and NBR-GE composites were exposed to an accelerated thermal ageing environment produced by an air-circulating oven for seven days. The mechanical properties, chemical changes, and thermal stability of ageing samples and neat samples were evaluated. The results showed that the surface damage of NBR was severe and inhomogeneous, and the degree of ageing was most serious on the edge region of the voids, but NBR-GE composites were changed slightly before and after ageing. The tensile strength increased with the increase of GE concentration, up to a maximum value, and decreased with further increases in GE concentration. The GE embedded crosslinked network limited the segment movement of chains in the stretch direction and played a role in the composites properties, and the GE sheets (contained the functional groups of $-\mathrm{OH},-\mathrm{C}=\mathrm{O}$ and $\mathrm{C}=\mathrm{C}$ ) after ageing. This behaviour may indicate greater interface adhesion between the GE and NBR. In addition, results obtained by thermogravimetric analysis (TGA) indicated that the thermal stability of NBR significantly changed with accelerated thermal ageing environment, but with addition of a certain amount of GE to NBR, the thermal stability of NBR could be improved. The NBR/GE composites exhibited good comprehensive performance with a mass fraction of GE of $10 \%$. Before and after the thermal ageing, the failure mechanism of NBR-GE composites appeared intergranular and ductile fracture, respectively.
\end{abstract}

Keywords

$N B R$, graphene, thermal ageing environment

\section{Introduction}

Rubber is one of the most useful classes of material, which is widely used in a broad range of fields, due to its toughness, elasticity, and permeability are required. ${ }^{1}$ Nitrile-butadiene rubber (NBR) has been widely used in industry for its high strength, good fatigue resistance, and corrosion resistance. NBR has great potential in safety defence, automobile and seals industries because of its low cost, excellent resistance to water, oil, fuels and greases, low abrasion rate, and good process ability. 2,3 However, the ageing resistance of NBR is sensitive to light, heat, oxygen, and other atmospheric factors because of the presence of an unsaturated back-bone of butadiene. ${ }^{4-6} \mathrm{~A}$ degrading environment, such as one characterized by high temperature, high humidity, strong light, low temperature, or a mechanical load, can have an obvious effect on NBR durability. ${ }^{7,8}$ The main failure of rubber is ageing, which greatly affects the service life of rubber. Recently, many researchers have investigated the preparation of different NBR-based nanocomposites, and improved ageing and mechanical properties, which further exploit the potentialities of NBR. ${ }^{9,10}$ Graphene (GE) and its relatives (e.g., graphene oxide and graphene nanoribbons) are promising candidates as fillers in NBR-based nanocomposites with the range of unique properties of these materials, such as high specific surface area, high thermal and electrical conductivity, mechanical strength and flexibility,

${ }^{*}$ Corresponding author: Dr Fei-Zhou Li

e-mail: Ifz-1010@163.com among many others. ${ }^{11-13}$ In fact, the process of rubber ageing is very slow, and takes a long time to degrade. Thus, accelerated ageing tests are typically applied in the study of rubber degradation in a short time. In previous works, ${ }^{14,15}$ the effects of thermo-oxidation and ultraviolet ageing on the physical properties of NBR have been investigated, the ageing behaviour and mechanism of NBR have been analysed. The aim of this work was to investigate the ageing behaviour and mechanism of degradation of NBR with GE in an accelerated thermal ageing environment. The effects of ageing are measured in terms of the changes in tensile strength, elongation at break and hardness. Microscopic analyses, thermogravimetric analyses, and the mechanical properties of nanocomposites were assessed before and after thermal ageing.

\section{Experimental}

\subsection{Materials}

The sulphur vulcanized NBR sheets of size $80 \mathrm{~mm} \times 120 \mathrm{~mm} \times 2 \mathrm{~mm}$ were supplied by our research team. The nitrile content was around $36 \%$. In addition to NBR, carbon black type N-330 (primary particle size 28-36 nm), zinc oxide, stearic acid, Vulcafor F, Dicumyl peroxide (DCP) and sulphur were obtained from Northwest Rubber \& Plastics Research and Design Institute (Xianyang, China). Graphene (GE), purity: >95 \%, scale: 
2-10 microns, layer: $<30$, was supplied by Chengdu Organic Chemicals, Co, Ltd., Chinese Academy of Sciences (Chengdu, China), the size and morphology of graphene sheet is shown in Fig. 1. To improve the ageing resistance of NBR, certain ion fractions $(w=2 \%, 5 \%, 10 \%, 15 \%$ and $20 \%$ ) of GE were also added to the NBR. The NBRGE preparation process refers to the study of Li Feizhou's Butadiene Rubber. ${ }^{16}$ The prepared sheet was shaped by hot pressing using a vulcanizing machine $\left(150{ }^{\circ} \mathrm{C}, 20 \mathrm{MPa}\right.$, and $60 \mathrm{~min}$ ), and the composites were used for the performance tests.

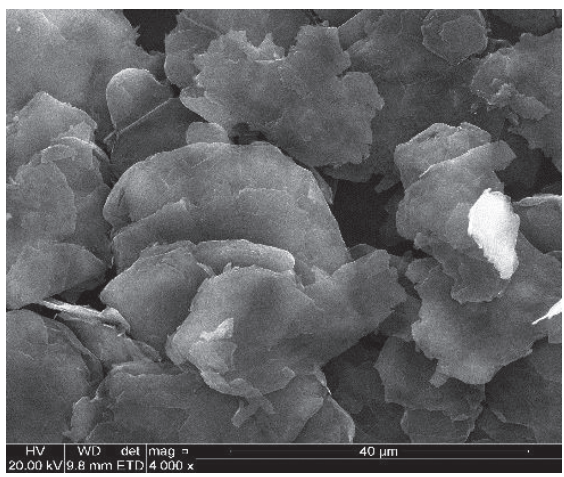

Fig. 1 - SEM of graphene sheet

\subsection{Thermal ageing}

Accelerated thermal ageing test was conducted by hot air-circulating oven equipment with temperature reaching precision of $1{ }^{\circ} \mathrm{C}$. The specimens were hung on the turntable and rotated at 1-10 rpm, in case they unevenly heated (incomprehensibly). The test temperature was set at $100{ }^{\circ} \mathrm{C}$ for up to seven days.

\subsection{Mechanical testing}

The mechanical properties of the NBR-GE composites were performed before and after seven days of thermal oxidation. At least three dumbbell-shaped tensile samples were tested for each kind of NBR-GE composite, and then the average was taken as the end result. The mechanical tests were performed according to the Chinese standard GB/T 528-2009. In order to study the effects of accelerated ageing on the tensile strength, the NBR and NBR-GE composites were made into dumbbell shaped specimens (Fig. 2) according to the ISO 4648-1978.

The strength loss rate was calculated by the following equation (Eq. 1):

$$
\eta=\frac{\sigma_{0}-\sigma}{\sigma_{0}}
$$

where $\sigma_{0}$ is the strength of composite before ageing, $\sigma$ is the strength of the composites after ageing, and $\eta$ is the strength loss rate.

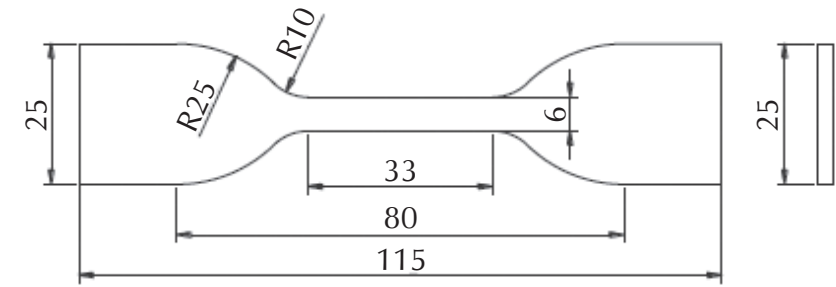

Fig. 2 - Sizes of the dumbbell-type samples

\subsection{Thermogravimetric (TGA) analysis}

The thermogravimetric analysis of NBR was performed by a STA449 F3 synchronous thermal analyser system under nitrogen atmosphere using an alumina crucible (Netzsch, Selb, Germany). Specimens weighing 10-15 mg were heated from 25 to $600{ }^{\circ} \mathrm{C}$ in nitrogen at a feed rate of $40 \mathrm{ml} \mathrm{min}{ }^{-1}$, and the heating rate was $15^{\circ} \mathrm{C} \mathrm{min}^{-1}$. The percentage of weight loss with rise in temperature was calculated to evaluate the thermal stability of all samples and onset decomposition temperatures were given.

\subsection{ATR-IR spectroscopy}

IR analysis was performed by a PerkinElmer Spectrum 100 FTIR (Norwalk, CT, USA) with an overhead attenuated total reflection accessory (ATR) at room temperature in the spectral region between 4000 and $700 \mathrm{~cm}^{-1}$ and a nominal resolution of $4 \mathrm{~cm}^{-1}$. Samples were used in the surface of a diamond in a form of a powder, and after measurement, the crystal was thoroughly washed. The cleaned crystal was carefully examined and checked with the background spectrum.

\subsection{Scanning electron microscopy (SEM)}

The surface morphology of the samples was studied by a Quanta FEG250 Scanning Electron Microscope (SEM; QUANTA FEG 250, USA) and performed at an accelerating voltage of $20 \mathrm{kV}$. The surface component analysis was investigated by an INCA Energy Dispersion Spectroscopy (EDS) and SEM.

\subsection{Dynamic mechanical analysis (DMA) tests}

The dynamic properties of NBR-GE composites and NBR were measured by a DMA Q800 machine (TA Instruments Ltd., New Castle, DE, USA), using rectangular specimens of about $15 \mathrm{~mm}$ in length, $1.5-2 \mathrm{~mm}$ width, and $2 \mathrm{~mm}$ thickness, and operated in film-tension mode. For the specimens, temperature sweep tests were performed with temperatures ranging from -70 to $50{ }^{\circ} \mathrm{C}$. The test frequency was fixed at $5 \mathrm{~Hz}$ and the dynamic deformation amplitude was set at $10 \mu \mathrm{m}$ or $50 \mu \mathrm{m}$ (tensile maximum dynamic strain $<25 \%$ ). 


\section{Results and discussion}

\subsection{Results of mechanical properties}

Fig. 3 shows the tensile strength of the composites with different concentrations of GE before and after thermal ageing. The tensile strength of the composites increased up to the mass fraction of GE of $10 \%$ and then decreased as the concentration of GE increased. Before thermal ageing, the values of the tensile strength of the composites were higher compared to the values after thermal ageing. For the pure NBR, the tensile strength decreased from 13.2 MPa before thermal ageing to $10.3 \mathrm{MPa}$ after thermal ageing. Compared to the pure NBR, the tensile strength of the composites with a mass fraction of GE of $10 \%$ increased $83 \%$ after thermal ageing.

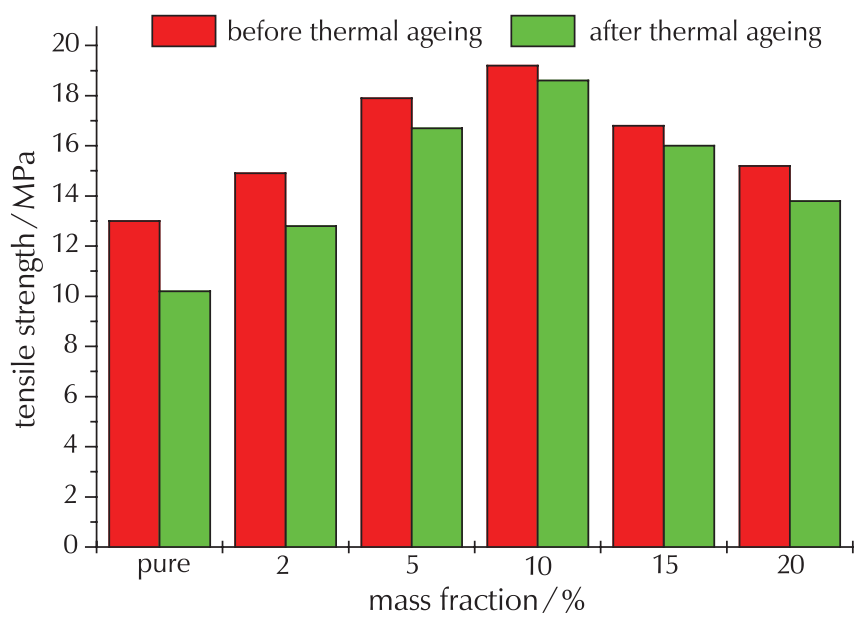

Fig. 3 - Tensile strength of NBR/GE composites

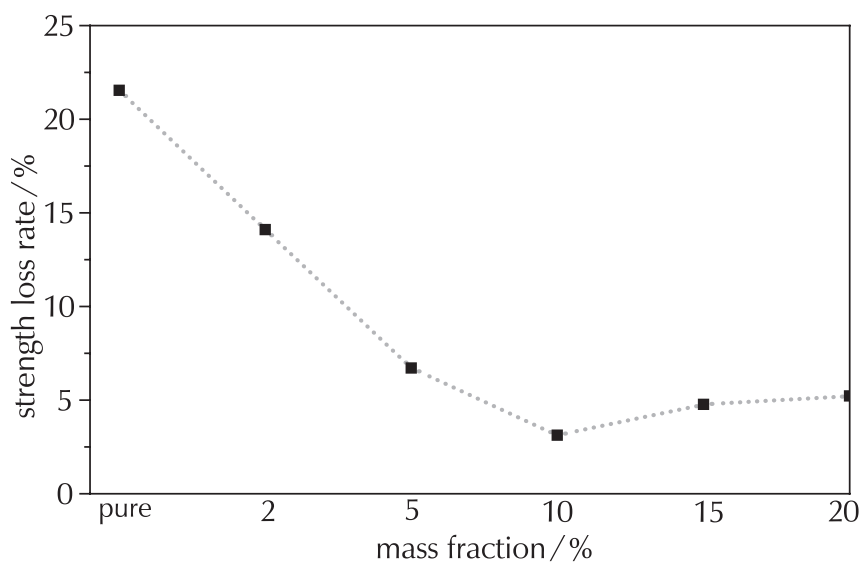

Fig. 4 - Strength loss rate of NBR/GE after thermal ageing

The strength loss rate of the composite with different concentrations of GE after thermal ageing is shown in Fig. 4. The figure shows that the tensile strength loss rates first de- creased to the mass fraction of GE of $10 \%$, and then increased slightly when the concentrations of GE increased. The tensile strength loss rate reached a minimum of $3.12 \%$ at a mass fraction of GE of $10 \%$.

The SEM results of the microstructure of the tensile failure section of NBR-GE composites indicated that the graphene sheets were well dispersed in NBR matrix, but the fracture mechanism was different before and after thermal ageing (see Fig. 5). Before thermal ageing, because of the low interface strength of graphene sheets and NBR matrix, the graphene sheets were pulled out and NBR matrix was not torn in interface, when the fracture surface appeared intergranular fracture. With the increase in GE concentration, the tensile strength of the composites increased, but the mass fraction of GE was exceeded ( $w=10 \%$ ) and NBR matrix was excessively divided, which led to the decreased strength (see Fig. 5e). After thermal ageing, graphene sheets were pulled out and NBR matrix was torn in interface, which fracture surface showed intergranular and ductile fracture. When the mass fraction of GE was lower than $10 \%$, the fracture surface indicated graphene sheets pulled out, obvious tearing and flat section of NBR matrix (see Fig. 5b). When the mass fraction of GE was $10 \%$, the fracture surface was tough tearing, following the massive strong nests and coarse fracture section of the NBR-GE composites, and then the interface strength of NBR-GE composites was stronger (see Fig. $5 \mathrm{~d}$ ). When the mass fraction of GE was more than $10 \%$, the fracture surface showed graphene sheets pulled out and obvious tearing, but flat section of NBR matrix (see Fig. $5 f$ ), and then indicated the interface strength of NBR-GE composites had decreased. Compared with the SEM before and after thermal ageing, it was determined that the interface of NBR-GE produced a certain reaction and contributed to increase in interface strength.

It was also observed that the Shore hardness of the composites before and after thermal ageing had slightly changed by adding GE to pure NBR, as shown in Table 1. Compared with the pure NBR, the gap of elongation at break decreased before and after thermal ageing. Based on the results above, adding GE can improve the tensile strength of NBR and increase the anti-ageing performance, perhaps because GE has high heat conductivity and could rapidly conduct out the heat and prevent the inside of the composites from becoming overheated. Alternatively, these results could be explained by the GE embedded crosslinked network, which limits the segment movement of chains in the stretch direction and plays a role in enhancing the Shore hardness of the composites. Experimental results showed that the composites exhibited a good comprehensive performance with a mass fraction of GE of $10 \%$. Another reason was that the sheet GE was oxidized in the process of thermal ageing, and the surface of GE possibly contained the functional groups of $-\mathrm{OH}, \mathrm{C}=\mathrm{O}$, and $\mathrm{C}=\mathrm{C}$, which contributed to forming greater interface adhesion between GE and NBR. ${ }^{17}$ 


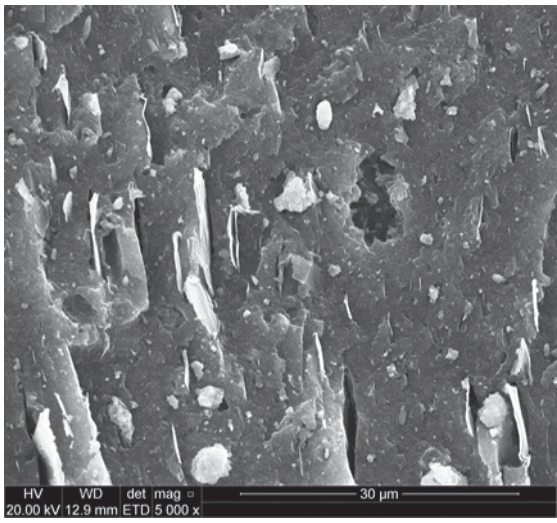

(a) before thermal ageing $(w(G E)=2 \%)$

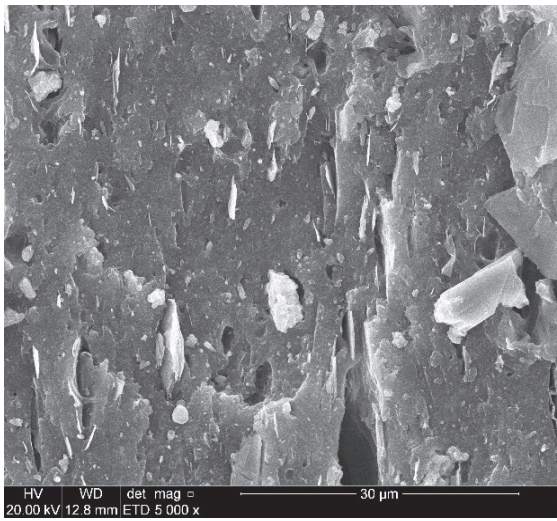

(c) before thermal ageing $(w(G E)=10 \%)$

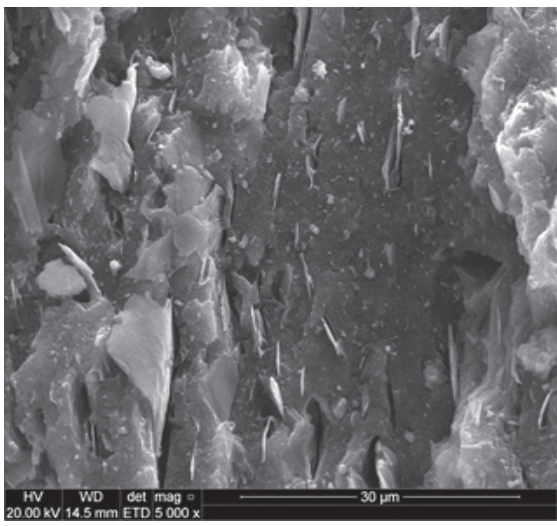

(e) before thermal ageing $(w(G E)=20 \%)$

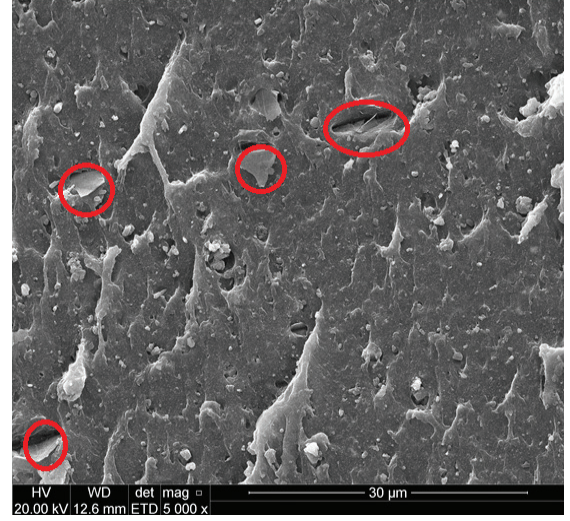

(b) after thermal ageing $(w(G E)=2 \%)$

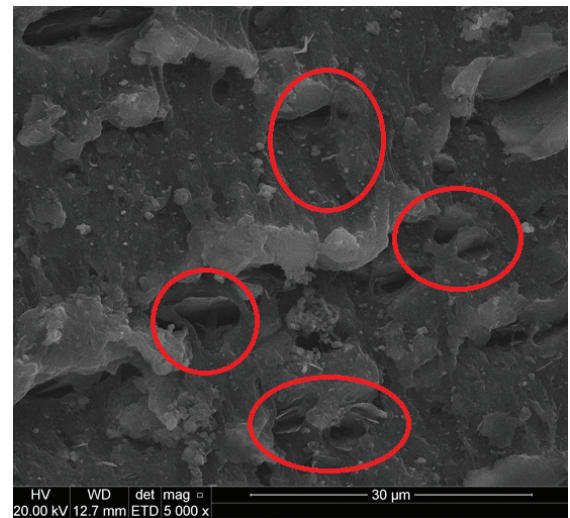

(d) after thermal ageing $(w(G E)=10 \%)$

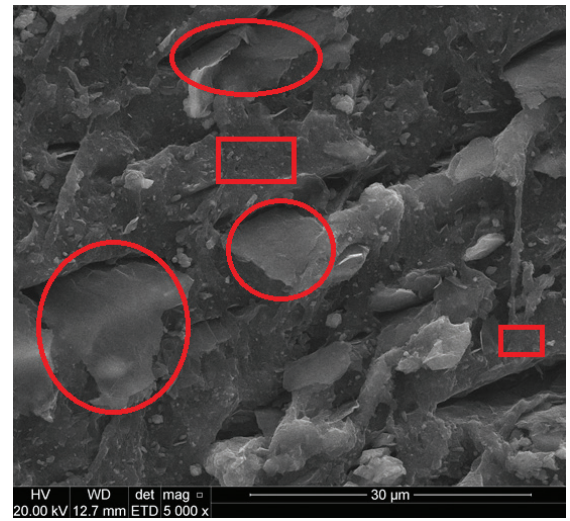

(f) after thermal ageing $(w(G E)=20 \%)$

Fig. 5 - SEM results of the tensile failure section of NBR-GE composites

Table 1 - Properties of the sample before and after ageing

\begin{tabular}{l|c|c|c|c|c}
\hline \multirow{2}{*}{$\begin{array}{l}\text { Sample } \\
\text { components }\end{array}$} & \multicolumn{2}{|c|}{ Shore hardness /A } & \multicolumn{2}{|c|}{$\begin{array}{c}\text { Elongation at } \\
\text { break/\% }\end{array}$} & $\begin{array}{c}\text { Permanent } \\
\text { set/mm }\end{array}$ \\
\cline { 2 - 6 } & $\begin{array}{c}\text { before } \\
\text { ageing }\end{array}$ & $\begin{array}{c}\text { after } \\
\text { ageing }\end{array}$ & $\begin{array}{c}\text { before } \\
\text { ageing }\end{array}$ & $\begin{array}{c}\text { after } \\
\text { ageing }\end{array}$ & $\begin{array}{c}\text { after } \\
\text { ageing }\end{array}$ \\
\hline NBR & 86 & 90 & 335 & 275 & 18 \\
NBR +2 \% & 90 & 92 & 180 & 150 & 7 \\
NBR +5 \% & 92 & 95 & 210 & 180 & 6 \\
NBR +10 \% & 93 & 93 & 215 & 200 & 14 \\
NBR +15 \% & 93 & 95 & 225 & 205 & 19 \\
NBR +20 \% & 92 & 94 & 220 & 195 & 21 \\
\hline
\end{tabular}

\subsection{ATR-FTIR analysis}

The FTIR spectra of NBR samples and the composites before and after thermal ageing for seven days are displayed in Fig. 6 . The figure shows that were nine characteristic peaks in the spectrum of the unaged NBR. The broad peak at $3210 \mathrm{~cm}^{-1}$ was due to $\mathrm{N}-\mathrm{H}$ stretching vibration and $\mathrm{O}-\mathrm{H}$ symmetric stretching vibration. The peaks at $2920.4 \mathrm{~cm}^{-1}$ and $2849.9 \mathrm{~cm}^{-1}$ corresponded to asymmetric stretching vibration of methylene in the saturated hydrocarbon backbone and symmetric stretching vibration of methylene, respectively. The peak at $2233.3 \mathrm{~cm}^{-1}$ was attributed to $-\mathrm{C} \equiv \mathrm{N}$ stretching vibration. The peak at $1590.3 \mathrm{~cm}^{-1}$ could be attributed to additives such as curing package. ${ }^{18}$ The peak at $1437.12 \mathrm{~cm}^{-1}$ was assigned to $-\mathrm{CH}_{2}$ - defor- 

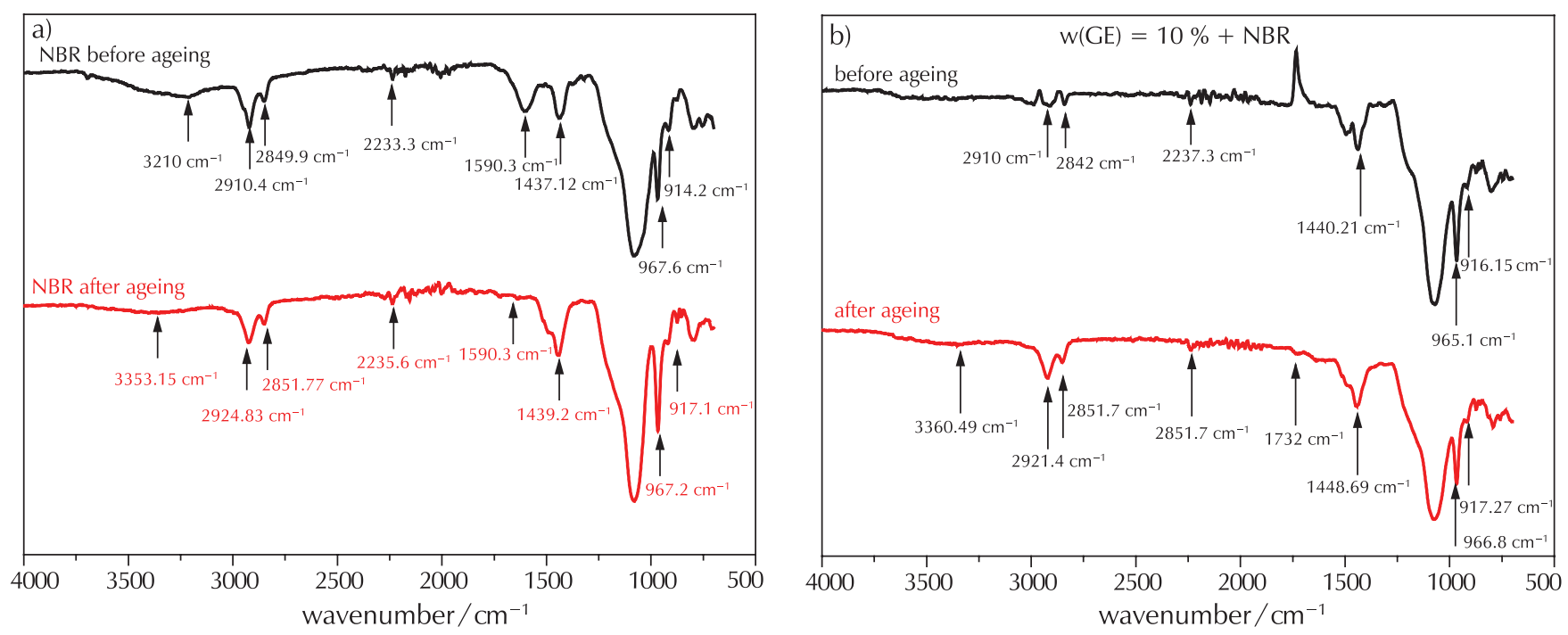

Fig. 6 - FT-IR spectra of composite samples

mation vibration, while the peak at $967.61 \mathrm{~cm}^{-1}$ was attributed to $\mathrm{C}-\mathrm{H}$ deformation vibration, which was characteristic of the trans-1,4 structure of the butadiene part. When the NBR samples were aged for seven days, the peaks at $3210 \mathrm{~cm}^{-1}, 2920.4 \mathrm{~cm}^{-1}, 2849.9 \mathrm{~cm}^{-1}$, $2233.3 \mathrm{~cm}^{-1}, 1437.12 \mathrm{~cm}^{-1}$, and $967.61 \mathrm{~cm}^{-1}$ were changed to $3353.15 \mathrm{~cm}^{-1}, 2924.83 \mathrm{~cm}^{-1}, 2851.77 \mathrm{~cm}^{-1}$, $2235.6 \mathrm{~cm}^{-1}, 1439.2 \mathrm{~cm}^{-1}$, and $967.2 \mathrm{~cm}^{-1}$, respectively. The peaks at $3210 \mathrm{~cm}^{-1}$ and $967.2 \mathrm{~cm}^{-1}$ increased in intensity remarkably, possibly because most of the antioxidants in the NBR samples had been consumed. The peak at $3210 \mathrm{~cm}^{-1}$ was mostly due to $\mathrm{O}-\mathrm{H}$ symmetric stretching vibration and $\mathrm{C}-\mathrm{H}$ deformation vibration. The prior analysis results indicate that hydroxyl groups were produced when the NBR was exposed to the accelerated thermal ageing environment.

The FTIR spectra of non-aged and aged NBR-GE composites are shown in Fig. 6b. In FT-IR, the important band of NBR at $914 \mathrm{~cm}^{-1}$ for 1,2-vinyl olefins, $967.61 \mathrm{~cm}^{-1}$ for 1,4-trans-olefin, $2920.40 \mathrm{~cm}^{-1}$ of $\mathrm{C}-\mathrm{H}$ stretching aliphatic peak, and $2233 \mathrm{~cm}^{-1}$ of $\mathrm{C}-\mathrm{N}$ stretching are seen to have a slight shift in the composite, which shows that there might be some interaction between the part of GE and NBR groups. After ageing, the peaks at $3360.49 \mathrm{~cm}^{-1}$, $2921.4 \mathrm{~cm}^{-1}$, and $1732 \mathrm{~cm}^{-1}$ increased in intensity and were broadened, which indicates that several oxygen-containing groups were produced in the ageing process. These three bands appeared more prominently in the NBR/GE sample, and this could be a combination frequency of the $\mathrm{CH}+\mathrm{OH}$ group, ${ }^{16,19}$ indicating cross-linking between NBR and GE.

\subsection{Thermogravimetric (TG) analysis}

From the point of decomposition and thermal stability of the NBR and GE anti-ageing performance, TGA is very important tool. TGA has demonstrated to be an appropriate

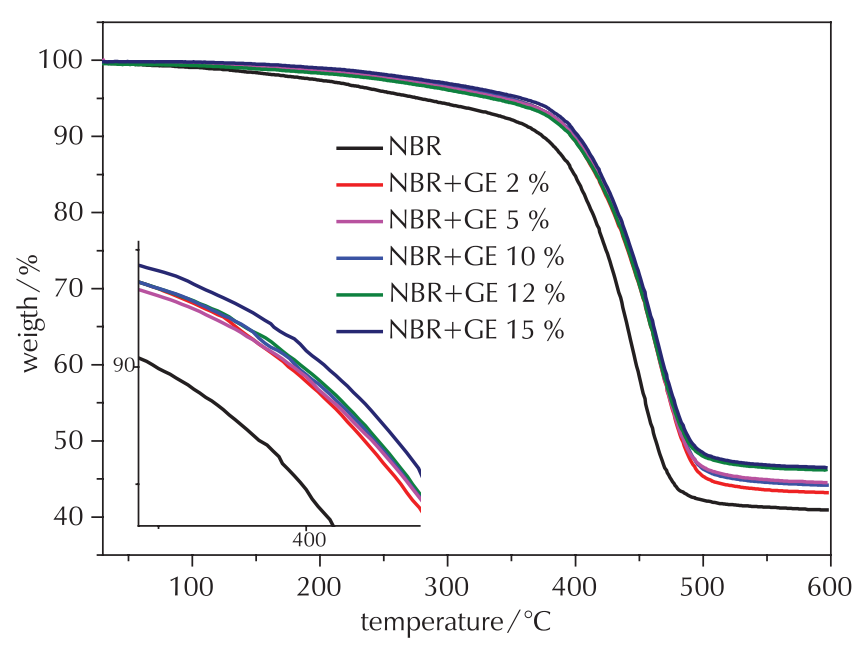

Fig. 7 - TGA plots of NBR and NBR-GE samples after thermal ageing for seven days

and reliable methodology to monitor the influence of degradation phenomena on polymeric materials. The results of the non-isothermal thermogravimetry are often used for determination of thermal stability of polymers and kinetic analysis. Fig. 7 and Table 2 show TGA plots of the NBR samples and NBR with different GE concentrations after thermal ageing for seven days. Fig. 7 shows that increased temperature, compared with NBR-GE composites, changed the weight loss of NBR in the ageing process. The weight loss of NBR samples and NBR-GE composites was $12 \%$ and $8 \%$ at $200{ }^{\circ} \mathrm{C}$, respectively. The composites were then decomposed completely from 300 to $500{ }^{\circ} \mathrm{C}$, and the weight loss of the NBR samples and NBR-GE composites was $52 \%$ and $48 \%$, respectively. Consequently, adding GE to NBR reduces NBR decomposition and contributes to the thermal stability and improves the anti-ageing performance. Table 2 shows that TG temperature $\left({ }^{\circ} \mathrm{C}\right)$ per weight loss and Onset Decomposition Temperature $\left(T_{d}\right)$ compared 
with NBR-GE composites, changed the weight loss of NBR in the ageing process. The weight loss of NBR samples composite was $5 \%$ at $277^{\circ} \mathrm{C}$, respectively. The weight loss of the NBR-GE composites was $5 \%$ at near $350^{\circ} \mathrm{C}$, respectively. From TG curves (mass vs. degradation temperature), and corresponding derivative thermogravimetric curves (DTG), many following characteristics can be determined: the onset temperature $\left(T_{\mathrm{d}}\right)$, the temperature at $10 \%$ weight loss $\left(T_{10 \%}\right)$. Consequently, adding GE to NBR reduces NBR decomposition, contributes to the thermal stability and improves the anti-ageing performance.

Table 2 - Onset decomposition temperature (Td), and TG Analysis results of $\mathrm{NBR}$ and $\mathrm{NBR} / \mathrm{GE}$

\begin{tabular}{l|c|c|c|c}
\hline \multirow{2}{*}{ Sample } & $\begin{array}{c}\text { Onset decomposition } \\
\text { temperature }\left(T_{\mathrm{d}}\right) /{ }^{\circ} \mathrm{C}\end{array}$ & \multicolumn{3}{|c}{$\begin{array}{c}\text { TG temperature per } \\
\text { weight loss } /{ }^{\circ} \mathrm{C}\end{array}$} \\
\cline { 3 - 5 } & 388.9 & $5 \%$ & $20 \%$ & $50 \%$ \\
\hline NBR & 426.6 & 327 & 429 & 483 \\
NBR+GE 2 \% & 428.3 & 343 & 431 & 485 \\
NBR+GE 5 \% & 426.7 & 344 & 432 & 484 \\
NBR+GE 10 \% & 426.8 & 347 & 433 & 487 \\
NBR+GE 12 \% & 428.8 & 358 & 434 & 491 \\
\hline
\end{tabular}

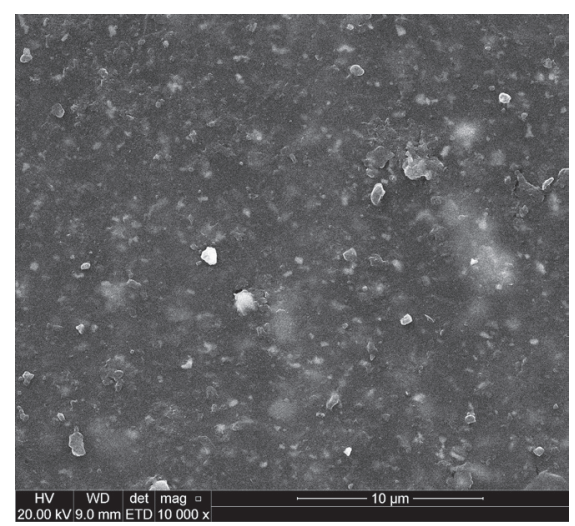

(a) non-aged NBR

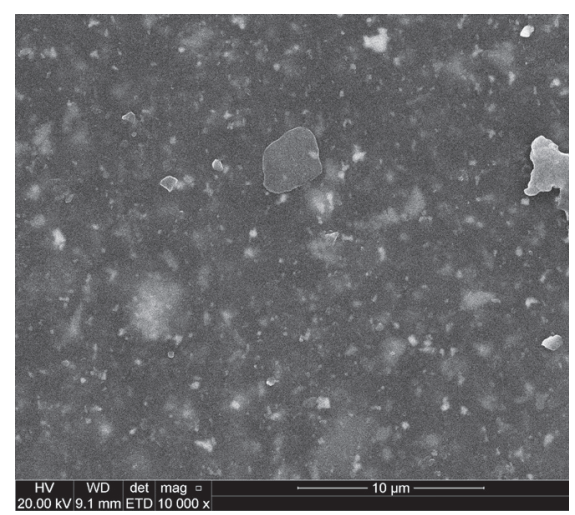

(c) non-aged NBR/GE

\subsection{Surface morphology and component analysis}

The morphology changes on the surface of samples before and after thermal ageing were obtained by SEM, as shown in Fig. 8. Apparently, the surface of the non-aged NBR and NBR/GE samples were relatively homogeneous and smooth with no obvious defects. After ageing for seven days, the surface of NBR turned rougher and the size of the voids became larger, but the size of the voids of the NBR/ GE samples was relatively small.

To conveniently analyse the degree of thermal ageing of the NBR and NBR/GE samples after seven days, the components of elements (e.g., oxygen) on the NBR surface were analysed by EDS. Three different regions were selected in Fig. 9, which correspond to the bottom of one void (Spectrum 3), the edge of voids (Spectrum 2), and the relatively-white spots (Spectrum 1). The atomic weight proportion of oxygen and carbon $(\mathrm{O} / \mathrm{C})$ was adopted to determine the order of the degradation reaction. ${ }^{2}$ Fig. 9 and Table 3 show that there were clear distinctions in the three regions: the proportion of Spectrum 3 was the highest, which means that the degree of thermal ageing was most serious for the edge region of voids of the NBR samples, and the proportion of Spectrum 1 was the lowest, which means that oxidation reactions were initiated from the surface of the NBR samples in the accelerated thermal ageing environment. Above all, adding GE to NBR can help prevent the thermal ageing of NBR.

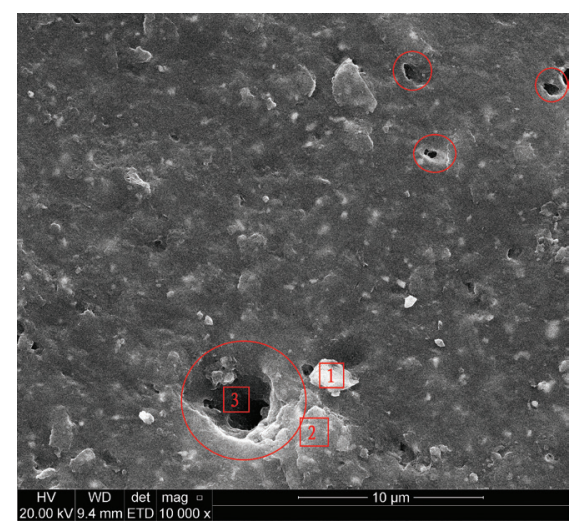

(b) aged NBR

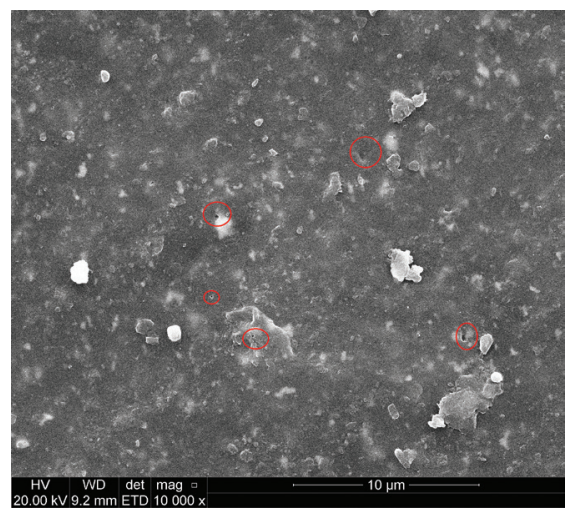

(d) aged NBR/GE

Fig. 8 - Surface of samples before and after thermal ageing were obtained by SEM 

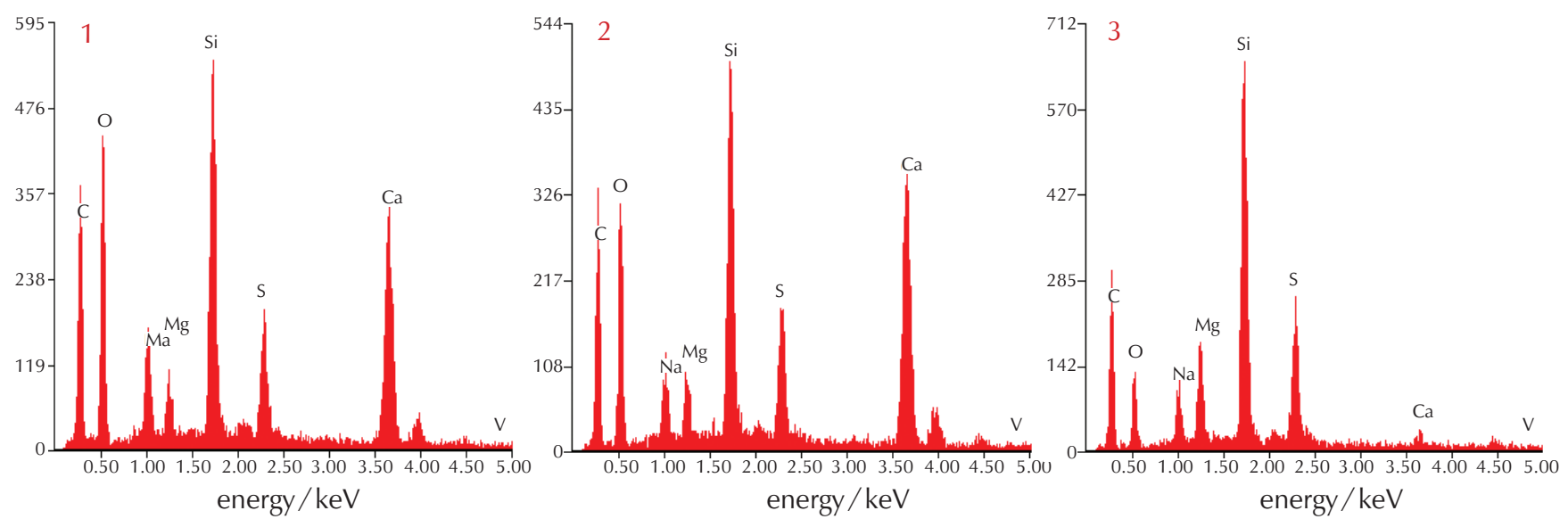

Fig. 9 - EDS spectra of NBR samples after thermal ageing for seven days

Table 3 - EDS results of NBR samples after thermal ageing for seven days

\begin{tabular}{c|c|c|c|c|c|c|c}
\hline Position & $w(\mathrm{C}) / \%$ & $w(\mathrm{O}) / \%$ & $w(\mathrm{Na}) / \%$ & $w(\mathrm{Mg}) / \%$ & $w(\mathrm{Si}) / \%$ & $w(\mathrm{~S}) / \%$ & $w(\mathrm{Ca}) / \%$ \\
\hline Spectrum 1 & 46.19 & 15.92 & 3.01 & 5.17 & 19.04 & 8.91 & 1.24 \\
Spectrum 2 & 29.77 & 31.36 & 3.37 & 2.47 & 11.8 & 5.16 & 15.78 \\
Spectrum 3 & 29.79 & 35.11 & 4.59 & 2.07 & 11.3 & 4.27 & 12.61 \\
\hline
\end{tabular}

\subsection{Results of DMA analysis}

The loss factor $(\tan \delta$ ) is the ratio of loss modulus to storage modulus. It is a measure of the energy lost from the material under loading at different temperatures, and it shows the internal friction or mechanical damping in a viscoelastic material. ${ }^{20}$ Loss factor $(\tan \delta$ ) is a damping term whose peak occurs in the glass transition region where the rubber changes from a rigid to a more elastic state. The peak height of $\tan \delta$ is mainly attributed to the motion of rubber chain segments that are initially frozen in Ref. Fig. 10 exhibits the loss $\tan \delta$ at different temperatures for neat NBR and NBR/GE composites. It is known that enhancement in interface strength in rubber composites occurs as observed by the depression in $\tan \delta$ values. The higher the damping at the interface is, the poorer the interface strength is. Compared to the peak height of $\tan \delta$ for the neat NBR, all of those for the five kinds of NBR composites are lower (Since the length is providing only the two kinds of NBR composites). NBR/GE composites showed the lowest depressed peak height of $\tan \delta$, proving that the largest amount of rubber chains segments are constrained approaching graphene sheet. Loss factors $(\tan \delta)$ of NBR/GE composites, compared to that of the neat NBR before and after ageing, were decreased slightly, but were still much higher than the neat aged value. The glass transition temperature $\left(T_{\mathrm{g}}\right)$ of neat NBR and NBR/GE composites before and after ageing were increased obviously from 1.55 and $5.7{ }^{\circ} \mathrm{C}$ to 7.87 and $9.42{ }^{\circ} \mathrm{C}$, respectively. The main reason is that the small amount of graphene could cause the breakdown of carbon black agglomerates, resulting in an increase in the fraction of bulk rubber matrix that can participate in glass transition, ${ }^{18}$ which improved the interface strength of NBR/GE composites.
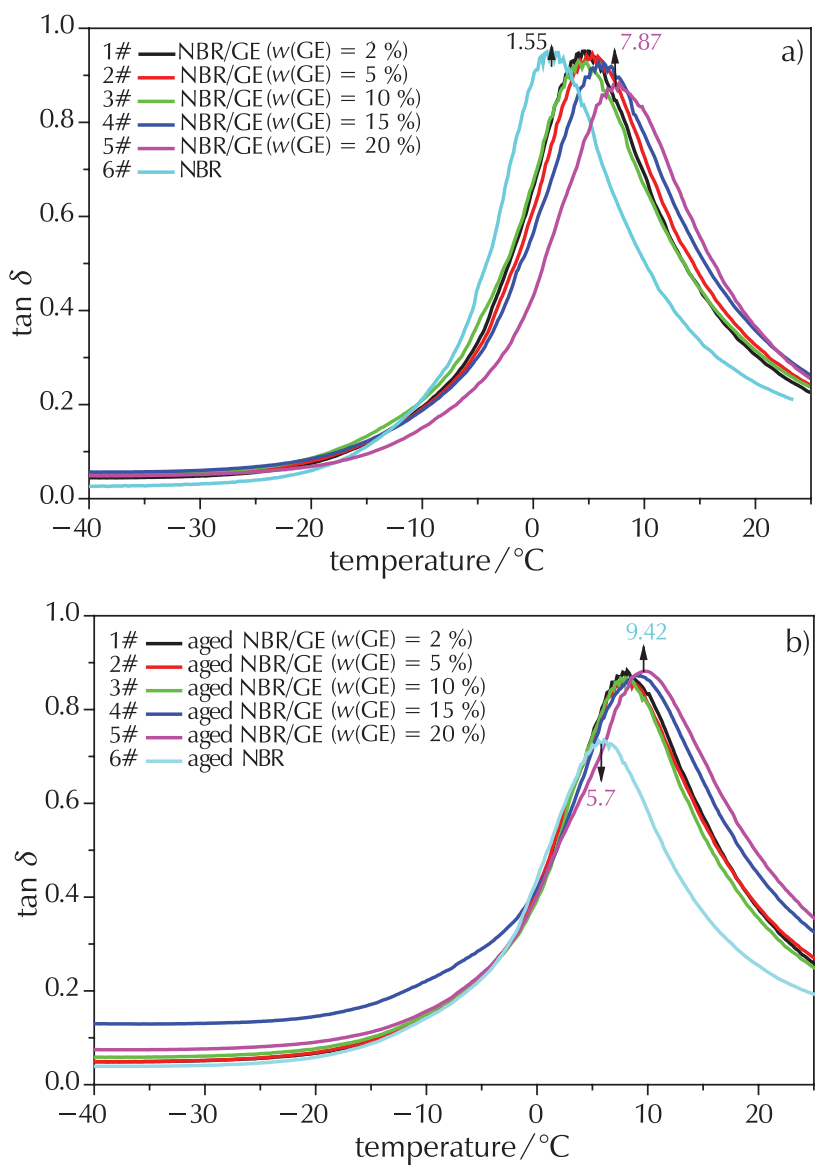

Fig. 10 - Loss factor (tan $\delta$ ) vs. temperature of NBR and NBR/GE before (a) and after (b) thermal ageing obtained by DMA 
From Fig. 10b, the loss factor peaks of NBR/GE composites were slightly changed compared to that of the neat NBR after ageing, which indicated that NBR/GE composites had good ageing properties. There was also evidence from the $\tan \delta$ and $T_{\mathrm{g}}$ results that some limited interaction between GE sheet and NBR molecular chains had occurred because of thermal ageing environment, indicating that the graphene filled NBR have good wet-skid resistance.

\section{Conclusions}

In this work, NBR and NBR/GE composites were prepared by melt-mixing in an open two-roll mill $\left(90{ }^{\circ} \mathrm{C}\right.$ with a rotor speed of $\left.50 \mathrm{rmin}^{-1}\right)$, and exposed to an accelerated thermal ageing environment produced by an air-circulating oven for seven days. The results showed that the surface damage of NBR was severe and inhomogeneous, and the degree of ageing was most serious on the edge region of voids, but NBR/GE composites were changed slightly before and after ageing. The tensile strength increased with increasing concentrations of GE, up to a maximum value, and decreased with further increase in GE concentration. The GE embedded crosslinked network limited the segment movement of chains in the stretch direction and played a role in enhancing the Shore hardness of composites. The surface of GE possibly contained the functional groups of $-\mathrm{OH},-\mathrm{C}=\mathrm{O}$, and $\mathrm{C}=\mathrm{C}$ after ageing, which contributed to forming greater interface adhesion between GE and NBR. In addition, the thermogravimetric analysis (TGA) indicated that the thermal stability of NBR significantly changed in the accelerated thermal ageing environment, but adding a certain amount of GE improved the thermal stability of the NBR. Before and after thermal ageing, the failure mechanism of NBR-GE composites appeared intergranular fracture and ductile fracture, respectively.

\section{ACKNOWLEDGEMENTS}

This study was supported by the State Forest Administration of China (Grant, No. 948-2015459) and the Science and Technology Program of China's Shaanxi Province (No. 2015GY146). The authors thank the anonymous reviewers for their useful comments, which contributed to the development of this paper.

\section{List of abbreviations}

$\begin{array}{ll}\text { ATR } & \text { - attenuated total reflection } \\ \text { DCP } & \text { - dicumyl peroxide } \\ \text { DMA } & \text { - dynamic mechanical analysis } \\ \text { EDS } & \text { - energy dispersion spectroscopy } \\ \text { NBR } & \text { - nitrile-butadiene rubber } \\ \text { GE } & \text { - graphene } \\ \text { SEM } & \text { - scanning electron microscopy } \\ \text { TGA } & \text { - thermogravimetric analysis }\end{array}$

\section{References} Literatura

1. J. Liu, X. B. Li, L. K. Xu, Investigation of aging behavior and mechanism of nitrile-butadiene rubber (NBR) in the accelerated thermal aging environment, J. Polym. Test. 54 (2016) 59-66, doi: https://doi.org/10.1016/j.polymertesting.2016.06.010.

2. T. Yasin, S. Ahmed, F. Yoshii, K. Makuuchi, Radiation vulcanization of acrylonitrile-butadiene rubber with polyfunctional monomers, J. React. Funct. Polym. 53 (2002) 173-181, doi: https://doi.org/10.1016/S1381-5148(02)00171-2.

3. F. S. Ahmed, M. Shafy, A. A. Abd El-megeed, The effect of $\gamma$-irradiation on acrylonitrile-butadiene rubber NBR seal materials with different antioxidants, J. Mater. Des. 36 (2012) 823828, doi: https://doi.org/10.1016/j.matdes.2011.02.066.

4. A. Mostafa, A. Abouel-Kasem, M. R. Bayoumi, The influence of CB loading on thermal aging resistance of SBR and NBR rubber compounds under different aging temperature, J. Mater. Des. 30 (2009) 791-795, doi: https://doi.org/10.1016/j. matdes.2008.05.065.

5. A. Kommling, M. Jaunich, D. Wolff, Effects of heterogeneous aging in compressed HNBR and EPDM O-ring seals, J. Polym. Degrad. Stab. 126 (2016) 39-46, doi: https://doi. org/10.1016/j.polymdegradstab.2016.01.012.

6. M. Jaunich, W. Stark, D. Wolff, Comparison of low temperature properties of different elastomer materials investigated by a new method for compression set measurement, J. Polym. Test. 31 (2012) 987-992, doi: https://doi. org/10.1016/j.polymertesting.2012.07.016.

7. M. Jaunich, D. Wolff, W. Stark, A new method to evaluate the low temperature function of rubber sealing materials, J. Polym. Test. 29 (2010) 815-823, doi: https://doi. org/10.1016/j.polymertesting.2010.07.006.

8. Y. T. Wei, L. Nasdala, H. Rothert, Experimental investigations on the dynamic mechanical properties of aged rubbers, J. Polym. Test. 23 (2004) 447-453, doi: https://doi. org/10.1016/j.polymertesting.2003.09.006.

9. X. Liu, J. H. Zhao, A novel in-situ aging evaluation method by FTIR and the application to thermal oxidized nitrile rubber, J. Polym. Degrad. Stab. 128 (2016) 99-106, doi: https://doi. org/10.1016/j.polymdegradstab.2016.03.008.

10. C. F. Matos, F. Galembeck, Multifunctional and environmentally friendly nanocomposites between natural rubber and graphene or graphene oxide, J. Carbon 78 (2014) 469-479, doi: https://doi.org/10.1016/j.carbon.2014.07.028.

11. Y. Zhan, M. Lavorgna, G. Buonocore, H. Xia, Enhancing electrical conductivity of rubber composites by constructing interconnected network of self-assembled graphene with latex mixing, J. Mater Chem. 22 (2012) 10464-10468, doi: https://doi.org/10.1039/c2jm31293j.

12. Z. Zhai, L. J. Feng, G. Z. Li, The anti-ultraviolet light (UV) aging property of aluminium particles/epoxy composite, Prog. Org. Coat. 101 (2016) 305-308, doi: https://doi. org/10.1016/j.porgcoat.2016.09.006.

13. W. Zheng, L. Liu, X. Y. Zhao, J. W. He, Effects of lanthanum complex on the thermo-oxidative aging of natural rubber, J. Polym. Degrad. Stab. 120 (2015) 377-383, doi: https://doi. org/10.1016/j.polymdegradstab.2015.07.024.

14. Y. H. Zhan, Y. Y. Meng, Electric heating behavior of flexible graphene/natural rubber conductor with self-healing conductive network, J. Mater. Lett. 192 (2017) 115-118, doi: https://doi.org/10.1016/j.matlet.2016.12.045.

15. J. H. Zhao, R. Yang, R. lervolino, Change of chemical structure and mechanical property levels during thermo-oxidative ag- 
ing of NBR, J. Rubber Chem. Technol. 86 (2013) 591-603, doi: https://doi.org/10.5254/RCT.13.87969.

16. F. Z. Li, Z. L. Lu, X.-S. Wang, Y. T. Xi, A combined experimental and molecular dynamics simulation study on the miscibility of Eucommia ulmoides gum with butadiene rubber, J. Polym. Res. 7 (2017) 97-113, doi: https://doi.org/10.1007/s10965017-1245-0.

17. Y. P. Wu, L. Chen, J. L. Li, Understanding the mechanical and tribological properties of solution styrene butadiene rubber composites based on partially graphene oxide, J. Europ. Polym. J. 89 (2017) 150-161, doi: https://doi.org/10.1016/j. eurpolymj.2017.02.017.
18. H. P. Mungse, O. P. Khatri, Chemically functionalized reduced graphene oxide as a novel material for reduction of friction and wear, J. J. Phys. Chem. C 118 (26) (2014) 14394-14402, doi: https://doi.org/10.1021/jp5033614.

19. S. Choudhary, H. P. Mungse, O. P. Khatri, Hydrothermal Deoxygenation of Graphene Oxide: Chemical and Structural Evolution, J. Chem. Asian J. 8 (9) (2013) 2070-2078, doi: https://doi.org/10.1002/asia.201300553.

20. G.-J. Cui , S.-W. Wang, P.-G. Yin, L. Guo, Study of Viscoelastic Properties of White Carbon Black Reinforced Synthetic Polyisoprene, Chin. J. Polym. Sci. (4) (2016) 457-465, doi: https://doi.org/10.1007/s10118-016-1765-9.

\title{
SAŽETAK
}

\author{
Ubrzano toplinsko starenje nitril-butadienskog kaučuka \\ $s$ dodanim grafenom \\ Fei-Zhou Li, Mu-Rong Gao i Bian Guo
}

\begin{abstract}
U ovom radu istraživano je toplinsko starenje nitril-butadienskog kaučuka (NBR) uz različite udjele grafena (GE). Kompoziti NBR i NBR-GE bili su izloženi ubrzanom toplinskom starenju koje je proizvodila zračna cirkulacijska pećnica tijekom sedam dana. Ispitivana su mehanička svojstva, kemijske promjene i toplinska stabilnost uzoraka starenja i čistih uzoraka. Rezultati su pokazali veliko i nehomogeno površinsko oštećenje NBR-a. Stupanj starenja bio je najozbiljniji na rubnom dijelu praznina, dok su se kompoziti NBR-GE prije i poslije starenja neznatno promijenili. S povećanjem koncentracije GE, vlačna čvrstoća se uvećala do maksimalne vrijednosti i smanjila s daljnjim povećanjem koncentracije GE. Ugrađena GE mreža ograničila je kretanje lanaca u smjeru rastezanja i odigrala ulogu u svojstvima kompozita i slojevima GE (sadržavali su funkcionalne skupine $-\mathrm{OH}$, $-\mathrm{C}=\mathrm{O}$ i $\mathrm{C}=\mathrm{C}$ ) nakon starenja. Ta pojava može ukazivati na veću međupovršinsku adheziju GE $\mathrm{i}$ NBR. Dodatno, rezultati dobiveni termogravimetrijskom analizom (TGA) pokazuju da se termička stabilnost NBR-a znatno promijenila s ubrzanim uvjetima toplinskog starenja, ali uz dodatak određene količine GE u NBR, može se poboljšati toplinska stabilnost NBR-a. Kompoziti NBR-GE pokazali su dobra sveobuhvatna svojstva s masenim udjelom GE od $10 \%$. Prije i nakon toplinskog starenja, mehanizam kvara kompozita NBR-GE pokazao je intergranularne i duktilne prijelome.
\end{abstract}

\section{Ključne riječi}

NBR, grafen, toplinsko starenje

Baoji University of Arts and Sciences

School of Mechanical

Baoji 721007

Kina
Izvorni znanstveni rad Prispjelo 16. listopada 2017. Prihvaćeno 20. prosinca 2017. 